\title{
6-gene promoter methylation assay is potentially applicable for prostate cancer clinical staging based on urine collection following prostatic massage
}

\author{
KOSTYANTYN A. NEKRASOV ${ }^{1}$, MARK V. VIKARCHUK ${ }^{2}$, EVGENIYA E. RUDENKO ${ }^{1}$, IGOR V. IVANITSKIY ${ }^{3}$, \\ VIACHESLAV M. GRYGORENKO ${ }^{2}$, ROSTYSLAV O. DANYLETS ${ }^{2}$, ALEXANDER G. KONDRATOV ${ }^{1}$, \\ LIUBOV A. STOLIAR ${ }^{1}$, BIZHAN R. SHAROPOV ${ }^{4,5}$ and VOLODYMYR I. KASHUBA ${ }^{1}$
}

\begin{abstract}
${ }^{1}$ Department of Molecular Oncogenetics, Institute of Molecular Biology and Genetics of The National Academy of Sciences of Ukraine, Kyiv 03143; ${ }^{2}$ Department of Reconstructive Urology and New Technologies, State Institution of The NAMSU, Kyiv 04053; ${ }^{3}$ Ukrainian Medical Stomatological Academy, Poltava 36000; ${ }^{4}$ Department of Nerve and Muscle Physiology, Bogomoletz Institute of Physiology of The National Academy of Sciences of Ukraine, Kyiv 01024; ${ }^{5}$ Department of Biology, National University of Kyiv-Mohyla Academy, Kyiv 04070, Ukraine
\end{abstract}

Received March 14, 2018; Accepted January 31, 2019

DOI: $10.3892 / \mathrm{ol} .2019 .11015$

\begin{abstract}
The detection of prostate cancer (PCa) biomarkers in bodily fluids, a process known as liquid biopsy, is a promising approach and particularly beneficial when performed in urine samples due to their maximal non-invasiveness requirement of collection. A number of gene panels proposed for this purpose have allowed discrimination between disease-free prostate and PCa; however, they bear no significant prognostic value. With the purpose to develop a gene panel for PCa diagnosis and prognosis, the methylation status of 17 cancer-associated genes were analyzed in urine cell-free DNA obtained from 31 patients with $\mathrm{PCa}$ and 33 control individuals using methylation-specific polymerase chain reaction (MSP). Among these, 13 genes indicated the increase in methylation frequency in patients with PCa compared with controls. No prior association has been reported between adenomatosis polyposis coli 2 (APC2), homeobox A9, Wnt family member 7A (WNT7A) and N-Myc downstream-regulated gene 4 protein genes with PCa. The 6-gene panel consisting of APC2, cadherin 1, forkhead box P1, leucine rich repeat containing $3 \mathrm{~B}, W N T 7 A$ and zinc family protein of the cerebellum 4 was subsequently developed providing $\mathrm{PCa}$ detection with $78 \%$ sensitivity and $100 \%$ specificity. The number of genes methylated (NGM) value introduced for this panel was indicated to rise monotonically from 0.27 in control
\end{abstract}

Correspondence to: Dr Bizhan R. Sharopov, Department of Nerve and Muscle Physiology, Bogomoletz Institute of Physiology of The National Academy of Sciences of Ukraine, 4 Bogomoletz Street, Kyiv 01024, Ukraine

E-mail: sharopov@biph.kiev.ua

Key words: prostate cancer, liquid biopsy, urine, cell-free DNA, gene methylation, biomarker individuals to 4.6 and 4.25 in patients with highly developed and metastatic $T_{2} / T_{3}$ stage cancer, respectively. Therefore, the approach of defining the NGM value may not only allow for the detection of PCa, but also provide a rough evaluation of tumor malignancy and metastatic potential by non-invasive MSP analysis of urine samples.

\section{Introduction}

According to the most recent global estimates in 2012, 307,000 and $\sim 3,000$ prostate cancer $(\mathrm{PCa}$ )-associated mortalities were reported globally and in Ukraine, respectively, and 1,111,700 and $\sim 7,000$ novel cases were diagnosed, respectively $(1,2)$. Although the advent of relatively non-invasive prostate-specific antigen (PSA) testing has notably improved PCa diagnosis, its routine usage remains controversial, since a false positive diagnosis rate of $\mathrm{PCa}$, over-treatment, and excessive medical spending has been reported (3-5). It has been reported that up to $75 \%$ of patients with elevated PSA level $(>4 \mathrm{ng} / \mu \mathrm{l})$ do not have any prostatic malignancy, although at least $1 / 3$ of aforementioned patients undergo subsequent invasive follow-up evaluation, including prostate biopsy (6). Additionally, 25\% of individuals with normal PSA level exhibit biopsy evidence for PCa $(7,8)$. Another important limitation of a canonical PSA assay is that it is neither a reliable discriminator between prostatic cancer and benign hyperplasia nor a precise staging indicator of $\mathrm{PCa}(4,5)$. Therefore, the development of an accurate, discriminative, and cost-efficient non-invasive $\mathrm{PCa}$ diagnostic tool is required.

Previous studies involving high-throughput techniques, including genome-wide sequencing, failed to identify a common genetic driver event (e.g. specific point mutation) in PCa tumorigenesis $(9,10)$. None of the recurrent mutations have been reported to appear in $40-50 \%$ of PCa cases, including transmembrane serine protease 2-ERG fusion and phosphatase and tensin homolog (PTEN) deletion (10). Additionally, when examined for alterations in DNA sequences, PCa 
demonstrates comparatively high clonal heterogeneity or even distinct genomic origin, complicating the use of mutation hotspots as tumor biomarkers (11). Instead it has been indicated that epigenetic alterations, including cytosine base followed immediately by a guanine base island methylation, occur in a number of loci in $80-90 \%$ of PCa cases, including methylation of glutathione S-transferase $\pi 1$ (GSTPl) gene promoter, may drive the neoplastic transformation and would be a preferable target for prostate cancer diagnosis and its biological potential assessment (11-13).

It has been previously proposed that the free-floating DNA fragments originating from the apoptotic/necrotic malignant cells in bodily fluids may be used for the detection of cancer biomarkers (14). This approach, also referred to as liquid biopsy, would be particularly beneficial when performed on urine samples, due to the maximal non-invasive requirements for its collection, which notably improves patient's compliance and safety (15). Urine contains notable amounts of cell-free DNA (UcfDNA) with a concentration of up to $250 \mathrm{ng} / \mathrm{ml}$ and consisting of the following two size category fragments: Long $(>1 \mathrm{~kb})$, which are primarily cell-associated, including from the exfoliated epithelium; and short (150-250 bp), which are predominantly non-cell associated and originate from urogenital tract per se or circulation $(16,17)$. This observation potentially makes UcfDNA the optimal source of data for diagnosing urogenital system cancer types. The prostate, whose lumen is continuously connected to the urogenital tract via prostatic sinuses, may be the optimal organ for investigation by means of UcfDNA analysis, which was successfully demonstrated by a number of studies (18-22).

In an effort to extend the list of biomarkers applicable for non-invasive PCa detection, the methylation profile of 17 cancer-associated genes was examined using the approach of UcfDNA analysis in the urine from patients with prostate cancer. From a functional perspective, the genes investigated in the present study are considered well-established tumor suppressors from earlier reports and participate in $\mathrm{PCa}$ pathogenesis [forkhead box P1 (FOXP1), FOXP3, FOXP4, hypermethylated in cancer $1(H I C 1)$, zinc finger protein of the cerebellum 4 (ZIC4), PTEN, cadherin 1 (CDH1), O-6-methylguanine-DNA methyltransferase $(M G M T)$ and leucine rich repeat containing $3 \mathrm{~B}(L R R C 3 B)]$ or are known to be associated with other malignancies [adenomatosis polyposis coli 2 (APC2), homeobox A9 (HOXA9), Wnt family member 7A (WNT7A) and N-Myc downstream-regulated gene 4 protein $(N D R G 4)](23,24)$. The protein products of FOXP1, FOXP3, FOXP4, ZIC4 and $H O X A 9$ are members of three families of transcription factors, including Forkhead, Zic, and HOX, which are broadly involved in the processes of tissue morphogenesis and cell differentiation $(13,22,25)$. A number of genes encode the extracellular and intracellular signaling proteins, including ligands (WNT7A), binding factors (APC2) and enzymes (NDRG4 and $P T E N)$, are known to take part in embryonic development and cell cycle regulation as well (26-28). E-cadherin encoded by the $C D H 1$ gene is a key adhesion molecule in the epithelial tissues crucial for the formation of adherent junctions, whose disruption results in tumor metastasis (29). The gene $M G M T$, which encodes the pivotal reparation enzyme MGMT, has been extensively implicated in the neoplastic transformation, due to the increased mutation rate following its silencing (29). The product of the $L R R C 3 B$ gene is a $29-\mathrm{kDa}$ membrane-bound protein, whose function, to the best of our knowledge, has yet to be defined; however, it has been reported to participate in the tumorigenesis of a number of human cancer types, including clear cell renal cell carcinoma (30).

In the present study this initial gene set was analyzed and 13 genes demonstrating a statistically significant increase in methylation frequency in the PCa group, compared with controls, were selected. A final panel of 6 genes, including $A P C 2, C D H 1, F O X P 1, L R R C 3 B$, WNT7A, and ZIC4, was formed based on zero/low methylation level in controls, with significant moderate-to-strong correlation with tumor stage, and no significant correlation with patient's age. Within the panel, the number of genes methylated (NGM) was observed to increase monotonically from control samples to highly developed and metastatic types of cancer, providing a simple and cost-efficient method to identify tumor stage using the NGM value in the urine sample.

\section{Materials and methods}

Patients sample collection. The present study was approved by the local Ethics Committee of the Institute of Molecular Biology and Genetics of the National Academy of Sciences of Ukraine (approval no. 18/4). Urine samples were collected between May and October 2017 from 64 individuals, including 31 patients diagnosed with $\mathrm{PCa}$ and receiving treatment at the Institute of Urology NAMSU, and 33 patients who were diagnosed as disease-free controls. Patient's detailed information is presented in Table I. None of the patients with PCa or control individuals underwent radical prostatectomy or any type of pharmacological treatment prior to sampling. All patients provided written informed consent to participate in the present study. In each case the diagnosis was further confirmed and the tumor was graded according to the Gleason scoring system on prostate biopsy followed by histological examination (31). The Tumour-node-metastasis (TNM) staging system was used to classify PCa cases according to their development and malignancy (32). Within the cancer group, individuals were categorized with localized, including $T_{1}$ and $T_{2} N_{0} M_{0} / N_{x} M_{0}$ ( $\mathrm{n}=5$ and $\mathrm{n}=9$, respectively) PCa, locally-advanced, including $\mathrm{T}_{3} \mathrm{~N}_{0} \mathrm{M}_{0}(\mathrm{n}=10) \mathrm{PCa}$, and metastatic, including $\mathrm{T}_{2} \mathrm{~N}_{\mathrm{x}} \mathrm{M}_{1} / \mathrm{N}_{1} \mathrm{M}_{1}$ and $T_{3} N_{1} M_{1}(n=3$ and $n=4$, respectively) $P C a$.

UcfDNA isolation. Voided urine $(50 \mathrm{ml})$ was harvested from patients following prostate massage on the previous day of definitive surgery. Each sample was spun at 3,000 x $\mathrm{g}$ for $10 \mathrm{~min}$ at room temperature, the supernatant was removed, and the pellet was washed twice with $1 \mathrm{X}$ PBS. The resultant pellet was cryopreserved at $-80^{\circ} \mathrm{C}$. Genomic DNA was extracted using a Quick-gDNA MiniPrep kit (Zymo Research Corp., Irvine, CA, USA), according to the manufacturer's protocol. The quality of isolated DNA was checked by $3 \%$ agarose gel electrophoresis. For the DNA concentration and purity measurements, a spectrophotometer ND-2000 (NanoDrop Technologies; Thermo Fisher Scientific, Inc., Waltham, MA, USA) was utilized.

Bisulfite treatment and methylation-specific real-time polymerase chain reaction (MSP). Extracted UcfDNA 
Table I. Clinical characteristics of patients.

\begin{tabular}{lcc}
\hline Variables & $\begin{array}{c}\mathrm{PCa}, \\
\mathrm{n}=31(\%)\end{array}$ & $\begin{array}{c}\text { Control, } \\
\mathrm{n}=33\end{array}$ \\
\hline $\begin{array}{l}\text { Age, years } \\
\text { Median }\end{array}$ & 66 & 62 \\
Range & $29-82$ & $37-88$ \\
Tumor stage (TNM classification) & & \\
$\mathrm{T}_{1}$ & $5(16)$ & - \\
$\mathrm{T}_{2} \mathrm{~N}_{0} \mathrm{M}_{0} / \mathrm{N}_{\mathrm{x}} \mathrm{M}_{0}$ & $9(29)$ & - \\
$\mathrm{T}_{3} \mathrm{~N}_{0} \mathrm{M}_{0}$ & $10(32)$ & - \\
$\mathrm{T}_{2} \mathrm{~N}_{\mathrm{x}} \mathrm{M}_{1} / \mathrm{N}_{1} \mathrm{M}_{1}$ & $3(10)$ & - \\
$\mathrm{T}_{3} \mathrm{~N}_{1} \mathrm{M}_{1}$ & $4(13)$ & - \\
PSA & & \\
Median & 37.7 & 2.0 \\
Range & $5.9-223.0$ & $0.2-4.1$ \\
Gleason score & & \\
6 & $10(32)$ & - \\
7 & $11(36)$ & - \\
8 & $3(10)$ & - \\
9 & $2(6)$ & - \\
9 & $5(16)$ & - \\
Unknown & $5(16)$ & - \\
\hline
\end{tabular}

-, not applicable; PCa, prostate cancer; PSA, prostate-specific antigen; $\mathrm{T}$, tumor; $\mathrm{N}$, node; $\mathrm{M}$, metastasis.

was subjected to bisulfite conversion using an EZ DNA Methylation kit (Zymo Research Corp.), according to manufacturer's protocol. MSP was conducted using 34 pairs of forward and reverse primers of methylated or unmethylated type. Nucleotide sequences are presented in Table II. All primers were designed with MethPrimer 2.0 online software (The Li Lab, Beijong, China; http://www.urogene.org/methprimer) and their performance was evaluated using $6 \%$ polyacrylamide gel electrophoresis. The size of the polymerase chain reaction products was within the range of $87-263 \mathrm{bp}$. Each reaction mix contained $2.5 \mu \mathrm{l}$ 10X DreamTaq buffer (Thermo Fisher Scientific, Inc.), $0.3 \mathrm{mM}$ primers, $100 \mathrm{ng}$ UcfDNA previously subjected to bisulfite conversion and nuclease-free water to a final volume of $25 \mu \mathrm{l}$. MSP was performed using thermocycler CFX96 Real-Time system (Bio-Rad Laboratories, Inc., Hercules, CA, USA), according to the following protocol: Initial $12-\mathrm{min}$ incubation at $95^{\circ} \mathrm{C}$, followed by 40 cycles of denaturation for $15 \mathrm{sec}$ at $95^{\circ} \mathrm{C}$, annealing for $30 \mathrm{sec}$ at $60^{\circ} \mathrm{C}$ and extension for $30 \mathrm{sec}$ at $72^{\circ} \mathrm{C}$.

Statistical analysis. Statistical analysis was performed using STATISTICA 7.0 software (StatSoft, Inc., Tulsa, OK, USA). Since the data obtained were not normally distributed, it was analyzed with a non-parametric approach. $\mathrm{P}<0.05$ was considered to indicate a statistically significant difference. The comparison of PCa and control groups for the methylation frequency in the 17 genes was conducted with Mann-Whitney U-test. The Spearman's rank correlation coefficient with
Bonferroni correction for multiple hypothesis testing was used to calculate correlation between methylation rate and patient's age or tumor stage. For this evaluation, the variables were measured on the ordinal scale. In the correlation analysis with regards to age, patients with $\mathrm{PCa}$ and controls were involved, while during the correlation analysis with regards to stage, only patients with cancer were taken into account. A resulting $\mathrm{R}$-value $>0.3$ along with $\mathrm{P}<0.05$ was considered to indicate a positive correlation between the values examined. The comparison of the control and five cancer groups after the NGM value was calculated was performed using the Kruskal-Wallis test with Conover's post-hoc analysis adjusted by the Benjamini-Hochberg false discovery rate method. The results are presented as the means \pm standard error of the mean.

\section{Results}

Examination of the methylation status of 17 genes in PCa and control groups. The methylation frequency of 17 gene promoters was evaluated in urine samples from patients with PCa and the control group (Table III). The increase in methylation frequency in tumor samples was the lowest for FOXP2 (3.03-6.45\%) and the highest for ZIC4 (6.06-58.06\%) genes, compared with controls. Among the panel analyzed, 8 genes, including $W N T 7 A, L R R C 3 B$, FOXP3, FOXP4, CDH1, HOXA9, NDRG4 and PTEN, were not methylated in all of the control samples. However, aforementioned genes were indicated to be methylated to different extents in prostate tissues from patients with PCa. On the contrary, 9 genes, including Von Hippel-Lindau tumor suppressor $(V H L)$, FOXP1, FOXP2, APC2, ZIC4, phospholipase C like 2 (PLCL2), $H I C 1$, ubiquitin conjugating enzyme E2 (UBE2E2) and MGMT were identified to be methylated in control and cancer groups. A statistically significant difference was indicated in the methylation status of the following 13 genes: WNT7A, LRRC3B, FOXP1, FOXP3, FOXP4, APC2, ZIC4, CDH1, HOXA9, NDRG4, PTEN, $M G M T$ and $H I C l$. All these genes, except $H I C l$, had a methylation frequency between $0-12 \%$ in the control samples, while in the PCa samples methylation frequency was between 13-58\%. The HICl gene demonstrated a notable methylation frequency even in control samples ( 39\%) and for this reason $\mathrm{HICl}$ was excluded in subsequent analyses. The difference in methylation status of VHL, FOXP2, PLCL2, and UBE2E2 genes was indicated to be statistically insignificant between cancer and control individuals (Table III).

The formation of the 6-gene diagnostic/prognostic panel based on correlation analysis. The correlation between the methylation of the considered genes and tumor stage was evaluated using the Spearman's rank test. A positive correlation was identified in the following 14 genes: VHL, WNT7A, LRRC3B, FOXP1, FOXP3, FOXP4, APC2, ZIC4, PLCL2, CDH1, HIC1, NDRG4, PTEN and $M G M T$. The genes FOXP3, FOXP4, NDRG4, PTEN and MGMT were excluded from subsequent analyses, due to a weak correlation with the disease stage. Furthermore, VHL was also excluded due to low statistical significance $(\mathrm{P}>0.05)$, following Bonferroni correction, in addition to a number of genes, including FOXP3, FOXP4 and PTEN, indicating a weak correlation. In contrast, 3 genes, FOXP2, HOXA9 and $U B E 2 E 2$, indicated negative values of correlation coefficient. However, they were also rejected due to the low correlation with tumor stage. 
Table II. Primers used for methylation-specific polymerase chain reaction.

\begin{tabular}{|c|c|c|c|}
\hline Genes & Forward 5'-3' & Reverse 5'-3' & Product size $(\mathrm{bp})$ \\
\hline \multicolumn{4}{|l|}{$A P C 2$} \\
\hline M & ATTTCGGGTCGGGATTTTC & GCTTACGTACAACTAAACTAACG & 135 \\
\hline $\mathrm{U}$ & GTTGTTTGTATTTGTTTGTTTTTGA & АААСАТААССТТАААСТССССАСТ & 136 \\
\hline \multicolumn{4}{|l|}{$\mathrm{CDHI}$} \\
\hline M & GGTTTTGACGTCGAGAGTTATAC & TACGTAAATTCCAAAAAATATCGTT & 211 \\
\hline $\mathrm{U}$ & TTTGGTTTTGATGTTGAGAGTTATATG & TACATAAATTCCAAAAAATATCATT & 214 \\
\hline \multicolumn{4}{|c|}{ FOXPl } \\
\hline $\mathrm{M}$ & CGGAGTTCGGAAAATTTAAATACGT & GTCTCGAAAAAACGAAAACCGA & 87 \\
\hline $\mathrm{U}$ & TGGAGTTTGGAAAATTTAAATATGT & TCATCTCAAAAAAACAAAAACCAAA & 89 \\
\hline \multicolumn{4}{|c|}{ 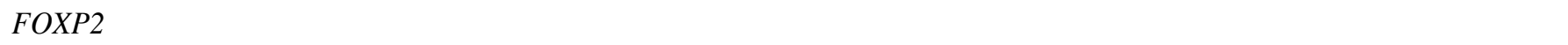 } \\
\hline $\mathrm{M}$ & CGTTTTTTCGAGGAGAGGTAGTTTC & GCGCGCGTATTATTAACAATACG & 101 \\
\hline $\mathrm{U}$ & TGTTTTTTTGAGGAGAGGTAGTTTT & ACACACATATTATTAACAATACAAA & 103 \\
\hline \multicolumn{4}{|c|}{ ( } \\
\hline M & GGATAGGGTAGTTAGTTTTCGGAAC & GAATACGCCGAACTTCATCGA & 93 \\
\hline $\mathrm{U}$ & ATAGGGTAGTTAGTTTTTGGAATGA & ACCAAATACACCAAАCTTCATCAAC & 94 \\
\hline \multicolumn{4}{|c|}{ FOXP4 } \\
\hline $\mathrm{M}$ & TTCGTAGTTATTCGTAGTTTAGGTTTAGTC & TCGCGAACTAAAAACTCCGT & 120 \\
\hline $\mathrm{U}$ & TTGTAGTTATTTGTAGTTTAGGTTTAGTTG & TCСТCACAAАCTAAAААСТCСАТСС & 122 \\
\hline \multicolumn{4}{|l|}{ HICl } \\
\hline $\mathrm{M}$ & TTTTATTAGTAATTTAATTCGAATAGCGTC & AACCGCAATCCTAAAAATCG & 138 \\
\hline $\mathrm{U}$ & TATTAGTAATTTAATTTGAATAGTGTTGG & TACAAAACCACAATCCTAAAAATCAC & 140 \\
\hline \multicolumn{4}{|c|}{ 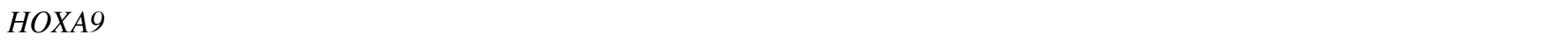 } \\
\hline $\mathrm{M}$ & ATCACCTAATAAATTAACCGACG & TCGGATTATTAATAGCGTGC & 101 \\
\hline $\mathrm{U}$ & TGTAGTTTTTAGTTTAAGGTGATGG & AATAATAATAATACACCACAACAAA & 100 \\
\hline \multicolumn{4}{|c|}{ (2) } \\
\hline M & GGTGCGAGGAAGGTAGGC & ACCAATACCTCGCCGACG & 222 \\
\hline $\mathrm{U}$ & TGGTGTAAGGTAAGGTGTAGTTGT & AAACAAAAACAAAAAAAATCAAC & 217 \\
\hline \multicolumn{4}{|c|}{$M G M T$} \\
\hline $\mathrm{M}$ & CGTTTGTAGTTGAGTAAGTATGAGTTTAG & AAACGACCCTAAATTCATCGAAAA & 263 \\
\hline $\mathrm{U}$ & GTTTTGGATATGTTGGGATAGTTTG & ACACCTAAAAAACACTTAAAACACA & 261 \\
\hline \multicolumn{4}{|c|}{ NDRG4 } \\
\hline M & GGTATTTTAGTCGCGTAGAAGGC & GTACCCGCGTAAATTTAACGAA & 119 \\
\hline $\mathrm{U}$ & GTTAGATAGGTGGGTTTTGTAGATG & CAAATCAAAACTAAAACAAAAACAC & 120 \\
\hline \multicolumn{4}{|l|}{ PLCL2 } \\
\hline $\mathrm{M}$ & GTATTTTTTTTCGGGAGAGTAAGTC & CCAAAAACGACTAAAAATAAACGAT & 105 \\
\hline $\mathrm{U}$ & TTTTTTTGGGAGAGTAAGTTGG & ССАAАAАCAACTAAAAATAAACAAT & 100 \\
\hline \multicolumn{4}{|c|}{ (2) } \\
\hline $\mathrm{M}$ & TTTTTTTATTTCGTTGTCGTCGT & TTAACGATAACTAATACCCCTCGC & 155 \\
\hline $\mathrm{U}$ & TTTTTTTTATTTTGTTGTTGTTGT & TTAACAATAACTAATACСССТСАCТ & 156 \\
\hline \multicolumn{4}{|c|}{$U B E 2 E 2$} \\
\hline M & ATTAGACGGTTCGTAGGGGATATTTC & ATATCCGTACAAATCGCAAACTCGA & 180 \\
\hline $\mathrm{U}$ & GAGATTGAGATTATGGTGAAATTTT & ACCCAAACTAAAATACAATAACACA & 181 \\
\hline \multicolumn{4}{|l|}{$V H L$} \\
\hline M & TTATTCGGGAGGTTGAGGCGAGAC & CGCAAAAAAATCCTCCAACACCGTAA & 103 \\
\hline $\mathrm{U}$ & AGGTAGGATATATTTAGGGTGATGT & ACTCCAACCTAAACAACAAAACAA & 105 \\
\hline \multicolumn{4}{|c|}{ WNT7A } \\
\hline M & CGAAACCGTCTATCGATACG & GTAGTTCGGCGTCGTTTTAC & 179 \\
\hline $\mathrm{U}$ & TTTTTTGATGTATATTAGGTTTGT & СТАААССАСАСТАССАСААТТТСАА & 178 \\
\hline \multicolumn{4}{|c|}{ 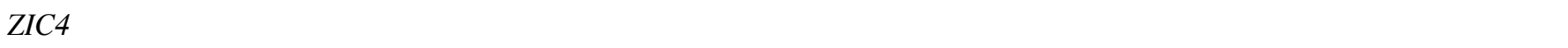 } \\
\hline M & GTTGTAGCGATAAGGTAGGAGTTTC & CCACTTTAACGAAATAAAAATCGAT & 202 \\
\hline $\mathrm{U}$ & TGTAGTGATAAGGTAGGAGTTTTGG & ССАCTTTAACAAAATAAAAATCAAT & 200 \\
\hline
\end{tabular}

M, methylated; U, unmethylated. 
Table III. Methylation status of 17 genes determined in urine.

\begin{tabular}{|c|c|c|c|c|c|c|}
\hline \multirow[b]{2}{*}{ Genes } & \multicolumn{3}{|c|}{ Methylation frequency, $\%$} & \multicolumn{2}{|c|}{ Age correlation (R-value) } & \multirow{2}{*}{$\begin{array}{l}\text { Stage correlation for } \\
\text { PCa group (R-value) }\end{array}$} \\
\hline & Control & $\mathrm{PCa}$ & U-test (P-value) & Control & $\mathrm{PCa}$ & \\
\hline$A P C 2^{\mathrm{a}}$ & 12.12 & 35.48 & $0.03^{\mathrm{a}}$ & 0.21 & 0.23 & $0.32^{\mathrm{b}}$ \\
\hline$C D H 1^{\mathrm{a}}$ & 0.00 & 48.39 & $<0.01^{\mathrm{a}}$ & 0.00 & 0.24 & $0.63^{\mathrm{b}}$ \\
\hline$F O X P 1^{\mathrm{a}}$ & 9.09 & 58.06 & $<0.01^{\mathrm{a}}$ & 0.22 & -0.20 & $0.41^{\mathrm{b}}$ \\
\hline$F O X P 2$ & 3.03 & 6.45 & 0.81 & 0.04 & 0.07 & -0.05 \\
\hline FOXP3 & 0.00 & 32.26 & $0.03^{\mathrm{a}}$ & 0.00 & -0.13 & 0.03 \\
\hline FOXP4 & 0.00 & 12.90 & $0.03^{\mathrm{a}}$ & 0.00 & -0.24 & 0.16 \\
\hline $\mathrm{HICl}$ & 39.39 & 90.32 & $<0.01^{\mathrm{a}}$ & 0.06 & -0.10 & $0.47^{b}$ \\
\hline НОХАЯ & 0.00 & 35.48 & $<0.01^{\mathrm{a}}$ & 0.00 & -0.09 & -0.01 \\
\hline$L R R C 3 B^{\mathrm{a}}$ & 0.00 & 19.35 & $0.01^{\mathrm{a}}$ & 0.00 & -0.06 & $0.31^{\mathrm{b}}$ \\
\hline$M G M T$ & 3.03 & 38.71 & $<0.01^{\mathrm{a}}$ & -0.20 & -0.18 & 0.01 \\
\hline NDRG4 & 0.00 & 32.26 & $<0.01^{\mathrm{a}}$ & 0.00 & 0.12 & 0.20 \\
\hline PLCL2 & 24.24 & 38.71 & 0.22 & $0.36^{\mathrm{b}}$ & -0.18 & 0.22 \\
\hline PTEN & 0.00 & 22.58 & $<0.01^{\mathrm{a}}$ & 0.00 & 0.06 & 0.05 \\
\hline$U B E 2 E 2$ & 3.03 & 9.68 & 0.28 & 0.18 & 0.11 & -0.20 \\
\hline$V H L$ & 6.06 & 22.58 & 0.06 & $-0.30^{\mathrm{b}}$ & 0.23 & $0.37^{\mathrm{b}}$ \\
\hline$W N T 7 A^{\mathrm{a}}$ & 0.00 & 41.94 & $<0.01^{\mathrm{a}}$ & 0.00 & 0.14 & $0.50^{\mathrm{b}}$ \\
\hline$Z I C 4^{\mathrm{a}}$ & 6.06 & 58.06 & $<0.01^{\mathrm{a}}$ & -0.08 & 0.22 & $0.41^{\mathrm{b}}$ \\
\hline
\end{tabular}

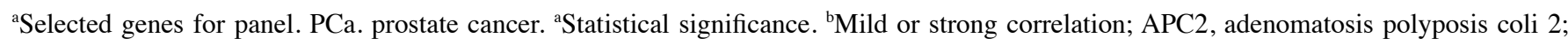
CDH1, cadherin 1; FOXP1, forkhead box P1; HIC1, hypermethylated in cancer 1; HOXA9, homeobox A9; LRRC3B, leucine rich repeat containing 3B; MGMT, O-6-methylguanine-DNA methyltransferase; NDRG4, N-Myc downstream-regulated gene 4 protein; PLCL2, phospholipase C like 2; PTEN, phosphatase and tensin homolog; UBE2E2, ubiquitin conjugating enzyme E2 E2; VHL, Von Hippel-Lindau tumor suppressor; WNT7A, Wnt family member 7A; ZIC4, zinc finger protein of the cerebellum 4.

Since PCa is a relatively slow-growing cancer, the actual age-associated methylation status dynamics may be misinterpreted as the respective alterations caused by tumor progression (6). Therefore, the correlation between patient's age with methylation of the gene panel investigated was also assessed (Table III). In the control group, $8 / 17$ genes indicated no correlation with age (WNT7A, LRRC3B, FOXP3, FOXP4, CDH1, HOXA9, NDRG4 and PTEN), 8 demonstrated weak correlation (VHL, FOXP1, FOXP2, APC2, ZIC4, HIC1, UBE2E2 and $M G M T$ ) and 1 exhibited moderate correlation (PLCL2). In the cancer group all genes were indicated to be weakly correlated with age. All 10 genes that indicated moderate correlation with tumor stage (VHL, WNT7A, LRRC3B, FOXP1, FOXP3, FOXP4, APC2, ZIC4, CDH1 and HIC1) demonstrated a notably weaker correlation with age (Table III).

Subsequently, the genes WNT7A, LRRC3B, FOXP1, APC2, ZIC4 and $C D H 1$ were selected to form a panel for PCa diagnosis in urine samples, according to the following four criteria: Low methylation frequency in control samples, statistically significant increase of methylation frequency in patients with $\mathrm{PCa}$, notable correlation with $\mathrm{PCa}$ progression, and 0 or weak correlation with age.

PCa detection and determination of the tumor stage by 'number of genes methylated' (NGM) approach. For the interpretation of the results obtained with the 6-gene panel, the 'number of genes methylated' (NGM) value ranging from
Table IV. The methylation of genes from 6-gene panel in PCa and controls.

\begin{tabular}{lcc}
\hline & \multicolumn{2}{c}{ Patients (n) } \\
\cline { 2 - 3 } Number of genes methylated & Control & PCa \\
\hline 0 & 24 & 3 \\
1 & 9 & 6 \\
2 & - & 6 \\
3 & - & 4 \\
4 & - & 9 \\
5 & - & 3 \\
6 & - & - \\
Total & 33 & 31 \\
\hline
\end{tabular}

PCa, prostate cancer; -, not applicable.

0 to 6 was introduced. With the cut-off value established at 2 , the panel provided PCa detection with $78 \%$ sensitivity and $100 \%$ specificity. In the control group NGM values were 0 for 24 patients and 1 for 9 patients, while none of them had $\geq 2$ methylated genes (Table IV). The NGM values of patients with $\mathrm{PCa}$ were uniformly distributed within the range of $0-5$ reflecting the tumor stage. The mean NGM value determined 
Table V. The number of genes methylated values in patients with different stages of prostate cancer.

\begin{tabular}{|c|c|c|c|c|c|c|c|c|c|c|}
\hline \multirow{2}{*}{$\begin{array}{l}\text { Panel genes } \\
\text { methylated }\end{array}$} & \multicolumn{2}{|l|}{$\mathrm{T}_{1}$} & \multicolumn{2}{|c|}{$\mathrm{T}_{2} \mathrm{~N}_{0} \mathrm{M}_{0} / \mathrm{N}_{\mathrm{x}} \mathrm{M}_{0}$} & \multicolumn{2}{|c|}{$\mathrm{T}_{3} \mathrm{~N}_{0} \mathrm{M}_{0}$} & \multicolumn{2}{|c|}{$\mathrm{T}_{2} \mathrm{~N}_{\mathrm{x}} \mathrm{M}_{1} / \mathrm{N}_{1} \mathrm{M}_{1}$} & \multicolumn{2}{|c|}{$\mathrm{T}_{3} \mathrm{~N}_{1} \mathrm{M}_{1}$} \\
\hline & Samples. n & $\%$ & Samples. n & $\%$ & Samples. n & $\%$ & Samples. n & $\%$ & Samples. n & $\%$ \\
\hline 0 & 3 & 60 & - & - & - & - & - & - & - & - \\
\hline 1 & 2 & 40 & 3 & 33 & 1 & 10 & - & - & - & - \\
\hline 2 & - & - & 3 & 33 & 3 & 30 & - & - & - & - \\
\hline 3 & - & - & 2 & 22 & 2 & 20 & - & - & - & - \\
\hline 4 & - & - & 1 & 12 & 4 & 40 & 1 & 33 & 3 & 75 \\
\hline 5 & - & - & - & - & - & - & 2 & 67 & 1 & 25 \\
\hline 6 & - & - & - & - & - & - & - & - & - & - \\
\hline Total & 5 & & 9 & & 10 & & 3 & & 4 & \\
\hline
\end{tabular}

-, not applicable; T, tumor; N, node; M, metastasis according to TNM staging system.

for each PCa stage group $\left(\mathrm{NGM}_{\text {aver }}\right)$ was indicated to almost monotonously rise from $0.27-4.25$ along with tumor progression and/or increase of its metastatic potential (Fig. 1). In particular, in the group with the least developed $\mathrm{T}_{1}$ stage cancer the NGM values overlapped with those in controls (0-1); however, it included more NGM 1 values, reaching $40 \%$ of the total number (Table V). Among the patients with non-metastatic PCa of $\mathrm{T}_{2} / \mathrm{T}_{3}$ stages, $15 / 19$ patients indicated NGM values between $2-4$, while only 4 patients had NGM values between $0-1$, as indicated in the control and $\mathrm{T}_{1}$ groups. Furthermore, none of the patients with metastatic cancer of $\mathrm{T}_{2} / \mathrm{T}_{3}$ stages demonstrated an NGM value $<4$, and in a number of cases an NGM value of 5 was reached.

The NGM approach was further tested for its prognostic potential. Although the resolving power of this method was not adequate to discriminate between all $5 \mathrm{PCa}$ and 1 control groups, it provided the discrimination between at least three categories of cases: controls and early cancer $\left(\mathrm{T}_{1}\right)$, developed cancer without metastases $\left(\mathrm{T}_{2} \mathrm{~N}_{0} \mathrm{M}_{0} / \mathrm{N}_{\mathrm{x}} \mathrm{M}_{0}\right.$ and $\left.\mathrm{T}_{3} \mathrm{~N}_{0} \mathrm{M}_{0}\right)$ and developed metastatic PCa $\left(\mathrm{T}_{2} \mathrm{~N}_{\mathrm{x}} \mathrm{M}_{1} / \mathrm{N}_{1} \mathrm{M}_{1}\right.$ and $\left.\mathrm{T}_{3} \mathrm{~N}_{1} \mathrm{M}_{1}\right)$ (Fig. 1). The $\mathrm{NGM}_{\text {aver }}$ of the control and $\mathrm{T}_{1}$ groups was $0.27 \pm 0.07$ and $0.40 \pm 0.24$, respectively, with no significant difference between the two groups, but with significant differences determined between neighboring groups without metastases, $\mathrm{T}_{2} \mathrm{~N}_{0} \mathrm{M}_{0} / \mathrm{N}_{\mathrm{x}} \mathrm{M}_{0}$ and $\mathrm{T}_{3} \mathrm{~N}_{0} \mathrm{M}_{0},(\mathrm{P}=0.02$ and $\mathrm{P}=0.0009$ between $\mathrm{T}_{1} / \mathrm{T}_{2}$ and $\mathrm{T}_{1} / \mathrm{T}_{3}$ groups, respectively). The latter groups also demonstrated an $\mathrm{NGM}_{\text {aver }}$ of $2.10 \pm 0.35$ and $2.90 \pm 0.34$, respectively, and could have not been statistically separated from each other, but differed from metastatic groups $\mathrm{T}_{2} \mathrm{~N}_{\mathrm{x}} \mathrm{M}_{1} / \mathrm{N}_{1} \mathrm{M}_{1}$ and $\mathrm{T}_{3} \mathrm{~N}_{1} \mathrm{M}_{1}(\mathrm{P}=0.0009$ and $\mathrm{P}=0.001$ comparing non-metastatic $\mathrm{T}_{2}$ and respective groups with metastases; $\mathrm{P}=0.01$ and $\mathrm{P}=0.02$ comparing non-metastatic $\mathrm{T}_{3}$ and the respective groups with metastases). Finally, the patients with invasive cancer $\mathrm{T}_{2} \mathrm{~N}_{\mathrm{x}} \mathrm{M}_{1} / \mathrm{N}_{1} \mathrm{M}_{1}$ and $\mathrm{T}_{3} \mathrm{~N}_{1} \mathrm{M}_{1}$ exhibited $\mathrm{NGM}_{\text {aver }}$ of $4.60 \pm 0.33$ and $4.25 \pm 0.25$, respectively, and exhibited no statistically significant difference between each other. Collectively, these data indicated that NGM value could be used to discriminate between PCa of three types: Early $\mathrm{T}_{1}$ cancer; $\mathrm{T}_{2} / \mathrm{T}_{3}$ cancer without metastases; and the highly invasive metastatic $\mathrm{T}_{2} / \mathrm{T}_{3}$ cancer stages.

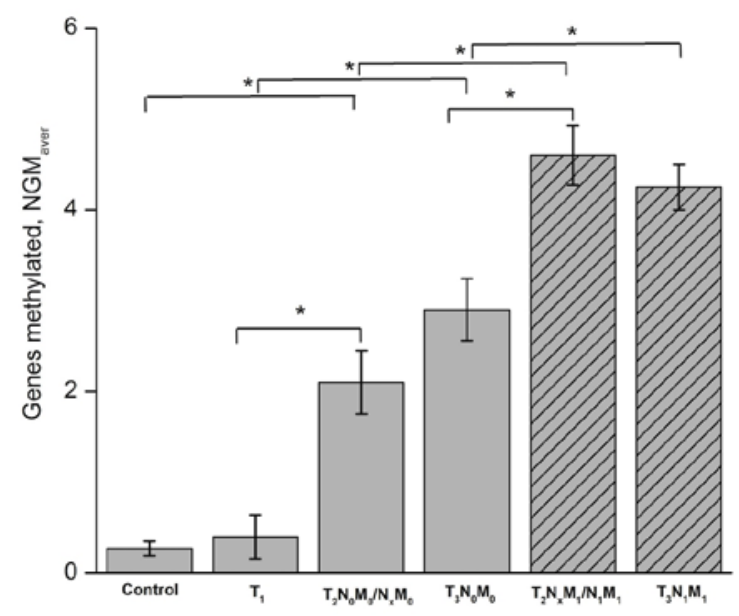

Figure 1. The dependence of NGM value on PCa tumor progression and metastasis development. The metastatic groups are marked with grid filling. NGM, number of genes methylated; $\mathrm{PCa}$, prostate cancer; T, tumor; N, node; $\mathrm{M}$, metastasis; $\mathrm{NGM}_{\text {aver }}$, average NGM. ${ }^{*} \mathrm{P}<0.05$.

\section{Discussion}

The present study identified 13 tumor suppressor genes undergoing aberrant methylation in prostate cancer, where 4 of these genes have no prior reported association with $\mathrm{PCa}$ pathogenesis (24-26). Furthermore, the present study proposes the diagnostic and prognostic panel of 6 genes, which may be used for non-invasive $\mathrm{PCa}$ detection and prognosis by non-invasive UcfDNA analysis.

Additionally, the correspondence of polymerase chain reaction data obtained from tissue samples and urine was examined. Despite the fact that the present study did not question the reliability of MSP analysis conducted on urine samples without examining the tumor per se, previous aforementioned advanced techniques made it possible to detect methylation events in urine, regardless of apparent UcfDNA fragmentation and its comparatively low amount (20). In a similar investigation, including the parallel examination of PCa tumor samples, it was demonstrated that a positive signal for a specific biomarker could be registered from urine in 
$85 \%$ of cases compared with the solid tissue samples (21). Furthermore, the urine was indicated to be the most amenable source of UcfDNA for cancer detection if compared with other types of bodily fluids, including blood and semen (21).

Novel genes associated with PCa were examined and the data of the present study indicated that the genes $A P C 2$, HOXA9, WNT7A and NDRG4 are associated with PCa pathogenesis. To the best of our knowledge, this has never been demonstrated on a DNA sequence alteration level or in epigenetic events. No methylation was indicated in HOXA9, WNT7A and NDRG4 genes in any of the control samples, while $A P C 2$ was methylated in $12 \%$ of the control samples. In the PCa samples methylation frequencies of aforementioned genes reached 35, 42, 32 and 35\%, respectively. It should be noted that the actual methylation rate of these genes in PCa may be even higher when determined in the tumor samples themselves, due to seemingly increased DNA integrity and amount in solid tissue, compared with the UcfDNA pool (17). Further detailed investigation is required to clarify the significance of these genes for $\mathrm{PCa}$ pathogenesis.

Therefore, the present study proposed a 6-gene panel consisting of APC2, CDH1, FOXP1, LRRC3B, WNT7A and ZIC4 allowing PCa detection with $78 \%$ sensitivity and $100 \%$ specificity. In a number of previous studies, other individual genes or their respective panels were considered as candidate PCa biomarkers for urine-based polymerase chain reaction diagnostics (20-21,33-35). In the present study, promoter hypermethylation in the GSTPl gene, the most frequent molecular event in $\mathrm{PCa}$ pathogenesis occurring in $80-90 \%$ of its cases, was detected in only $27 \%$ of urine samples, while the respective biopsy samples indicated methylation frequency of $79 \%$, which is consistent with previous reports $(12,20)$. Although the sensitivity of this test appeared to be inadequate for clinical application, it demonstrated the practical feasibility of urine polymerase chain reaction/MSP examination for PCa diagnosis (20). In another study, it was reported that the detection rate in UcfDNA analysis may be increased notably by selecting more appropriate experimental conditions: When using a DNA isolation kit developed for blood/tissue samples, the study reported GSTP1 promoter hypermethylation in only $36 \%$ of urine samples from patients with PCa, but switching to a viral kit allowed the detection of this molecular event in $76 \%$ of cases investigated (21). Furthermore, the use of differential display code $3\left(D D 3^{P C A 3}\right)$, a gene expressing a non-coding RNA highly specific for prostate tissue, was proposed as a non-invasive $\mathrm{PCa}$ detection method. The diagnostic test based on the quantitative determination of its transcripts in urine was reported to exhibit $67 \%$ sensitivity and a $90 \%$ negative predictive value (33). In another study, the use of the p16, p14 ${ }^{A R F}, M G M T$ and GSTPI gene combination, instead of focusing on a single gene, provided a diagnostic test with $87 \%$ sensitivity along with $100 \%$ specificity (34). Additionally, a gene panel consisting of GSTP1, Ras association domain family member 1A, retinoic acid receptor $\beta 2$ and $A P C 1$ was proposed for detection of localized $\mathrm{PCa}$, yielding a sensitivity and accuracy of 86 and $89 \%$, respectively (35).

The main advantage of the 6-gene panel proposed in the present study over the aforementioned is the prognostic value it may bear, as the tumor stage could be at least roughly deter-

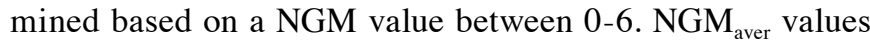
calculated in the cohort rose monotonically from the control group, 0.27 , to groups with $\mathrm{T}_{2}$ and $\mathrm{T}_{3}$ metastatic cancer types, 4.6 and 4.25, respectively. This indicated an increased probability of identifying malignant and metastatic tumor types in a patient with an increased individual NGM value. The number of genes included in this 6-gene panel is increased, compared with the 4-gene panels proposed by Hoque et al (34) and Roupret et al (35), which indicates a disadvantage in terms of cost-efficiency; however, it is necessary for distinguishing between PCa cases of different stages and metastatic potential. It is also important that a 6-gene set is amenable so that it can be applied in a single-tube multiplex polymerase chain reaction screen, providing maximal cost-efficiency and convenience. The cut-off NGM value of 2 was selected as a diagnostic criterion of $\mathrm{PCa}$, since the NGM values of individuals without a diagnosed prostate malignancy and $T_{1}$ cancer extensively overlapped in the range of $0-1$. The aforementioned disadvantage is mitigated by the fact that prostate cancer at $T_{1}$ stage is usually a small localized slow-growing tumor frequently left untreated, due to its asymptomatic nature, and the additional age-associated health problems that the patient with PCa may exhibit.

The main limitation of the present study is the relatively small patient cohort, including 31 individuals with PCa, while other studies of this type usually involve a broader cohort of patients, including $67 \mathrm{PCa}$ cases in the study by Salvi et al (22), and 52 cases in the study by Hoque et al (34). Nevertheless, the number of patients involved in the present study allowed the identification of methylation for 13 genes in PCa, and the establishment of the correlation with tumor stage for 8 of them with adequate statistical significance. Therefore, although the 6-gene panel proposed in the present study may not be yet applicable in a clinical setting, it could still be potentially used for this purpose following additional verification. Furthermore, separate genes from the selected panel, whose methylation frequency, according to the present data, was increased in the PCa group, compared with controls, could be introduced in other detecting or prognostic panels. The same applies for the comparison of cancer subgroups with different PCa stages using the NGM value parameter. Although the NGM value tends to rise with tumor development, the application of this tool for clinical use requires more precise determination of the correspondence between its particular values and the PCa stage.

Furthermore, the prognostic potential of the NGM approach has its own limitations. Clinical conclusions drawn can only be of a probabilistic nature, according to the present data, as NGM values obtained from patients with close PCa stages partially overlapped. However, at more distant tumor stages, NGM values significantly differed, including 0-1 at $\mathrm{T}_{1}$ and 4-5 at late metastatic stages. Therefore, it was demonstrated that the NGM approach serves as a valuable tool for further development of the panel proposed here or other gene panels designed for PCa prognosis.

\section{Acknowledgements}

Not applicable. 


\section{Funding}

The present study was supported by Science and Technology Center of Ukraine (grant no. 6056). The funding body had no role in the study design, data collection, its analysis and interpretation and article writing.

\section{Availability of data and materials}

The datasets used and/or analyzed during the current study are available from the corresponding author on reasonable request

\section{Authors' contributions}

MVV, IVI, VMG and ROD provided clinical material from patients with prostate cancer and control individuals. AGK and KAN designed the initial panel of cancer-associated genes and performed primer design. KAN and EER conducted the UcfDNA isolation and its MSP analysis. LAS, BRS and VIK conducted data analysis and wrote the article.

\section{Ethics approval and consent to participate}

The study was approved by local Ethics Committee of the Institute of Molecular Biology and Genetics of the National Academy of Sciences of Ukraine (approval no. 18/4 from 15th July 2016). All patients provided written informed consent to take part in the present study including further publication of the results obtained.

\section{Patient consent for publication}

All patients provided written informed consent for this study.

\section{Competing interests}

The authors declare no conflict of interests.

\section{References}

1. Torre LA, Bray F, Siegel RL, Ferlay J, Lortet-Tieulent J and Jemal A: Global cancer statistics, 2012. CA Cancer J Clin 65: 87-108, 2015.

2. Cancer in Ukraine 2012-2013: Bulletin of National Cancer Registry of Ukraine №15: Accessed 17: 10, 2017.

3. Rao AR, Motiwala HG and Karim OM: The discovery of prostate-specific antigen. BJU Int 101: 5-10, 2008.

4. Nogueira L, Corradi R and Eastham JA: Prostatic specific antigen for prostate cancer detection. Int Braz J Urol 35 521-532, 2009.

5. Loeb S and Catalona WJ: Prostate-specific antigen in clinical practice. Cancer Lett 249: 30-39, 2007.

6. Walter LC, Fung KZ, Kirby KA, Shi Y, Espaldon R, O'Brien S, Freedland SJ, Powell AA and Hoffman RM: Five-year downstream outcomes following prostate-specific antigen screening in older men. JAMA Intern Med 173: 866-873, 2013.

7. Thompson IM, Pauler DK, Goodman PJ, Tangen CM, Lucia MS, Parnes HL, Minasian LM, Ford LG, Lippman SM, Crawford ED, et al: Prevalence of prostate cancer among men with a prostate-specific antigen level $<$ or $=4.0 \mathrm{ng}$ per milliliter. N Engl J Med 350: 2239-2246, 2004.

8. Sunami E, Shinozaki M, Higano CS, Wollman R, Dorff TB, Tucker SJ, Martinez SR, Mizuno R, Singer FR and Hoon DS: Multimarker circulating DNA assay for assessing blood of prostate cancer patients. Clin Chem 55: 559-567, 2009.
9. Frank S, Nelson $\mathrm{P}$ and Vasioukhin V: Recent advances in prostate cancer research: Large-scale genomic analyses reveal novel driver mutations and DNA repair defects. F1000Res 7: pii: F1000 Faculty Rev-1173, 2018.

10. Barbieri CE, Bangma CH, Bjartell A, Catto JW, Culig Z, Grönberg H, Luo J, Visakorpi T and Rubin MA: The mutational landscape of prostate cancer. Eur Urol 64: 567-576, 2013.

11. Massie CE, Mills IG and Lynch AG: The importance of DNA methylation in prostate cancer development. J Steroid Biochem Mol Biol 166: 1-15, 2017.

12. Lee WH, Isaacs WB, Bova GS and Nelson WG: CG island methylation changes near the GSTP1 gene in prostatic carcinoma cells detected using the polymerase chain reaction: A new prostate cancer biomarker. Cancer Epidemiol Biomarkers Prev 6: 443-450, 1997.

13. Li LC: Epigenetics of prostate cancer. Front Biosci 12: 3377-3397, 2007.

14. Wan JCM, Massie C, Garcia-Corbacho J, Mouliere F, Brenton JD, Caldas C, Pacey S, Baird R and Rosenfeld N: Liquid biopsies come of age: Towards implementation of circulating tumour DNA. Nat Rev Cancer 17: 223-238, 2017.

15. Salvi S, Martignano F, Molinari C, Gurioli G, Calistri D, De Giorgi U, Conteduca V and Casadio V: The potential use of urine cell free DNA as a marker for cancer. Expert Rev Mol Diagn 16: 1283-1290, 2016

16. Zancan M, Galdi F, Di Tonno F, Mazzariol C, Orlando C, Malentacchi F, Agostini M, Maran M, Del Bianco P, Fabricio AS, et al: Evaluation of cell-free DNA in urine as a marker for bladder cancer diagnosis. Int J Biol Markers 24: 147-155, 2009.

17. Su YH, Wang M, Brenner DE, Ng A, Melkonyan H, Umansky S, Syngal $S$ and Block TM: Human urine contains small, 150 to 250 nucleotide-sized, soluble DNA derived from the circulation and may be useful in the detection of colorectal cancer. J Mol Diagn 6: 101-107, 2004.

18. Xia Y, Huang CC, Dittmar R, Du M, Wang Y, Liu H, Shenoy N, Wang L and Kohli M: Copy number variations in urine cell free DNA as biomarkers in advanced prostate cancer. Oncotarget 7: 35818-35831, 2016.

19. Bryzgunova OE, Morozkin ES, Yarmoschuk SV, Vlassov VV and Laktionov PP: Methylation-specific sequencing of GSTP1 gene promoter in circulating/extracellular DNA from blood and urine of healthy donors and prostate cancer patients. Ann N Y Acad Sci 1137: 222-225, 2008.

20. Cairns P, Esteller M, Herman JG, Schoenberg M, Jeronimo C, Sanchez-Cespedes M, Chow NH, Grasso M, Wu L, Westra WB and Sidransky D: Molecular detection of prostate cancer in urine by GSTP1 hypermethylation. Clin Cancer Res 7: 2727-2730, 2001.

21. Goessl C, Müller M, Heicappell R, Krause H, Straub B, Schrader $M$ and Miller K: DNA-based detection of prostate cancer in urine after prostatic massage. Urology 58: 335-338, 2001.

22. Salvi S, Gurioli G, Martignano F, Foca F, Gunelli R, Cicchetti G, De Giorgi U, Zoli W, Calistri D and Casadio V: Urine cell-free DNA integrity analysis for early detection of prostate cancer patients. Dis Markers 2015: 574120, 2015.

23. Takayama K, Suzuki T, Tsutsumi S, Fujimura T, Takahashi S, Homma Y, Urano T, Aburatani $\mathrm{H}$ and Inoue S: Integrative analysis of FOXP1 function reveals a tumor-suppressive effect in prostate cancer. Mol Endocrinol 28: 2012-2024, 2014.

24. Calvo R, West J, Franklin W, Erickson P, Bemis L, Li E, Helfrich B, Bunn P, Roche J, Brambilla E, et al: Altered HOX and WNT7A expression in human lung cancer. Proc Natl Acad Sci USA 97: 12776-12781, 2000.

25. Bhatlekar S, Fields JZ and Boman BM: HOX genes and their role in the development of human cancers. J Mol Med (Berl) 92: 811-823, 2014.

26. Daly CS, Shaw P, Ordonez LD, Williams GT, Quist J, Grigoriadis A, Van Es JH, Clevers H, Clarke AR and Reed KR: Functional redundancy between Apc and Apc2 regulates tissue homeostasis and prevents tumorigenesis in murine mammary epithelium. Oncogene 36: 1793-1803, 2017.

27. Phin S, Moore MW and Cotter PD: Genomic rearrangements of PTEN in prostate cancer. Front Oncol 3: 240, 2013.

28. Ding W, Zhang J, Yoon JG, Shi D, Foltz G and Lin B: NDRG4 is downregulated in glioblastoma and inhibits cell proliferation. OMICS 16: 263-267, 2012. 
29. Kang GH, Lee S, Lee HJ and Hwang KS: Aberrant CpG island hypermethylation of multiple genes in prostate cancer and prostatic intraepithelial neoplasia. J Pathol 202: 233-240, 2004.

30. Kondratov AG, Stoliar LA, Kvasha SM, Gordiyuk VV, Zgonnyk YM, Gerashchenko AV, Vozianov AF, Rynditch AV, Zabarovsky ER and Kashuba VI: Methylation pattern of the putative tumor-suppressor gene LRRC3B promoter in clear cell renal cell carcinomas. Mol Med Rep 5: 509-512, 2012.

31. Chen $\mathrm{N}$ and Zhou Q: The evolving Gleason grading system. Chin J Cancer Res 28: 58-64, 2016.

32. Schröder FH, Hermanek P, Denis L, Fair WR, Gospodarowicz MK and Pavone-Macaluso M: The TNM classification of prostate cancer. Prostate Suppl 4: 129-138, 1992.
33. Hessels D, Klein Gunnewiek JM, van Oort I, Karthaus HF, van Leenders GJ, van Balken B, Kiemeney LA, Witjes JA and Schalken JA: DD3(PCA3)-based molecular urine analysis for the diagnosis of prostate cancer. Eur Urol 44: 8-16, 2003.

34. Hoque MO, Topaloglu O, Begum S, Henrique R, Rosenbaum E, Van Criekinge W, Westra WH and Sidransky D: Quantitative methylation-specific polymerase chain reaction gene patterns in urine sediment distinguish prostate cancer patients from control subjects. J Clin Oncol 23: 6569-6575, 2005.

35. Rouprêt M, Hupertan V, Yates DR, Catto JW, Rehman I, Meuth M, Ricci S, Lacave R, Cancel-Tassin G, de la Taille A, et al: Molecular detection of localized prostate cancer using quantitative methylation-specific PCR on urinary cells obtained following prostate massage. Clin Cancer Res 13: 1720-1725, 2007. 